\title{
Psp68, A Dead Box Helicase Confers Salinity Tolerance in Transgenic Pigeon Pea
}

\author{
Neha and Pushpa Kharb* \\ College of Basic Sciences and humanities, CCS HAU, Hisar, Haryana, India \\ *Corresponding author
}

\section{Ke ywords}

Agrobacterium

Transformation,

Transgenic, Physio-

biochemical

analysis

Article Info

Accepted:

04 March 2019

Available Online:

10 April 2019

\section{A B S T R A C T}

Legumes are an important part of human diet account for about $27 \%$ of global primary crop production. Pigeon pea is the world's sixth most important and second most important legume pulse crop of India after chickpea and mainly cultivated as rain fed crop. Its production is adversely affected due to salinity in arid and semi-arid regions of world. Salt stress reduces water potential, creates imbalance in ion concentration and causes toxicity. Helicases have been shown to play an important role in plants against salt stress. p68 which is a prototype member of DEAD-box helicase interacts with $\mathrm{Ca}^{2+}-\mathrm{CaM}$, thus regulating diverse signalling pathways against salt stress in plants. In the present study, we have developed transgenic pigeon pea plants with marker free gene Psp68 for salinity tolerance. Since regeneration is prerequisite for transgenic development and pigeon pea is considered to be recalcitrant, the transgenic pigeon pea plants containing Psp68 gene have been developed using the tissue culture independent transformation method (Patent Application No. 201811012099). The putative $\mathrm{T}_{0}$ plants were screened by PCR analysis and the PCR positive plants with transformation efficiency of $16 \%$ were observed. Transgenic lines in $T_{1}$ generation under salt stress condition showed enhanced tolerance to salt stress in terms of various physio-biochemical parameters like relative water content, membrane injury index, MDA content, chlorophyll content, proline and total soluble sugar content, catalase activity and peroxidase activity.

\section{Introduction}

Abiotic stress is the principal cause of decreasing the average yield of major crops by more than $50 \%$, leading to the losses worth hundreds of million dollars each year (Rasool et al., 2013; Lamaoui et al., 2018). Among abiotic stresses, high salinity stress is the most severe environmental stress, which impairs crop production on at least $20 \%$ of irrigated land worldwide. Out of the 1500 million hectares agricultural land, 32 million $(2 \%)$ is affected by secondary salinity of varying degrees. Further, problems will be worsened as near about $50 \%$ of the arable land will hit salinity by 2050 (Machado and Serralheiro, 2017). Extensive economic losses due to salinity include costs of $\$ 27$ billion-plus loss of crop value per year (Kumar et al., 2017). Salinity affects various morphological and 
physio-biochemical processes involved in plant growth and development (Rahneshan et al., 2018). Soluble salts when present in excess cause ion toxicity and ion imbalance (Munns, 2005) which ultimately lead to plant demise (Zorb et al., 2018). In response to high salinity stress various genes get up regulated, the products of which are either directly or indirectly involved in plant protection (Shivakumara et al., 2017). Overall, the susceptibility or tolerance to high salinity stress in plants is a coordinated action of multiple stress responsive genes, which also cross-talk with other components of stress signal transduction pathways. The complexity and polygenic nature of salt stress are important factors contributing to the difficulties in breeding salt-tolerant crop varieties (Zhu, 2000; Flowers, 2004; Jangra et al., 2017). Understanding these mechanisms of stress tolerance along with a plethora of genes involved in stress signaling network is important to improve high salinity stress tolerance in crops plants. Since long conventional breeding has been widely used to develop stress tolerant and high yielding crop plants through screening of tolerant germplasm and crossing with cultivated varieties but this procedure is timeconsuming, cost and labour intensive (Ashraf, 2010; Yu et al., 2016) and suffers from a poor selectivity, due to transfer of unwanted linked traits along with desirable traits. Moreover, reproductive barrier and low level of variations in genetic pool make it a cumbersome technique. To resolve these barriers associated with traditional breeding, biotechnological approaches such as genetic engineering can be employed to obtain better results in shorter time.

Transgenic approach is being effectively pursued by plant scientists these days to impart salinity tolerance in various crop plants. Transgenics for salinity tolerance is mainly focused on introduction of genes that encode ion transport proteins, compatible organic solutes, antioxidants and transcriptional factors for gene regulation (Ashraf et al., 2008). A large number of these genetic processes demand the intervention of several types of essential enzymes including helicases. The helicases are ubiquitous enzymes that catalyze the unwinding of energetically stable duplex DNA (DNA helicases) or duplex RNA secondary structures (RNA helicases) (Tuteja, 1997; Tuteja, 2000; Tuteja and Tuteja 2004; Gustafson and Wessel, 2010; Linder and Fuller-Pace, 2013). Helicases might be playing an important role in stabilising growth in plants under stress by regulating stress-induced transcription and translation. A hallmark of most of the helicases is the existence of a set of highly conserved amino acid sequences called 'helicase-motifs', which are clustered together for helicase function (Tuteja and Tuteja, 2004a; 2004b). One of the important motifs is DEAD (motif II), which stands for Asp-Glu-Ala-Asp. The DEAD-box RNA helicases is the largest family of RNA helicases. In spite of the sequence resemblance of DEAD-box RNA helicases within the core helicase regions, each DEADbox helicase is believed to play various crucial roles in plant growth and development (Linder and Jankowsky, 2011). Jiechen, (2016) reported that transgenic lines of cotton plants overexpressing Apocynumvenetum DEAD-box helicase $1(A v D H 1)$ showed lower membrane ion leakage, along with increased activity of superoxide dismutase thus confering salinity tolerance. In Arabidopsis, DEAD-box protein LOS4 (low expression of osmotically responsive genes 4) and RCF1 (regulator of $C B F$ gene expression 1) has been validated to be essential in exporting mRNA and pre-mRNA splicing by regulating the expression of $\mathrm{CBF}$ (C-repeat binding factor) factor under cold stress conditions (Gong et al., 2005; Guan et al., 2013). Three DEAD-box RNA helicases AtRH5, AtRH9 
and AtRH25 also respond to multiple abiotic stresses in Arabidopsis (Kant et al., 2007; Kim et al., 2008). A rice DEAD-box RNA helicase OsBIRH1 (Oryza sativa BTHinduced RNA helicase 1) was shown to function in defense responses against pathogen and oxidative stresses ( $\mathrm{Li}$ et al., 2008). All these reports suggest roles of plant helicases in stress tolerance however, the exact role of most plant DEAD-box proteins largely remains unclear and requires further studies.

The p68 is a prototype member of DEAD-box family and it plays a very important role in cell/organ development (Stevenson et al., 1998) and also participates in a variety of biological processes in animal system including pre-rRNA processing (Liu, 2002; Bates et al., 2005; Fuller-Pace, 2006), RNAinduced gene silencing (Ishizuka et al., 2002), transcription initiation (Fuller-Pace, 2006) and alternative splicing processes (Kar et al., 2011). It was also reported that ATPase activity of recombinant p68 in yeast was stimulated by double-stranded RNA and it unwinds RNA in both $3^{\prime}$ to $5^{\prime}$ and $5^{\prime}$ to $3^{\prime}$ directions (Huang and Liu, 2002. It has been reported that p68 RNA helicase is phosphorylated on tyrosine, serine, and threonine residues and its helicase and ATPase activities are stimulated after phosphorylation with protein kinase C (Pradhan et al., 2005b) which is a general cascade to cope with abiotic stresses in plants. Wang et al., (2013) reported that p68 also interacts with $\mathrm{Ca}^{2+}-\mathrm{CaM}$ regulating diverse signalling pathways leading to stress tolerance in plants.

Psp68 DEAD-box protein exhibits ATPase activity in the presence of both DNA and RNA, binds to DNA as well as RNA and shows unique bipolar DNA helicase activity which suggest that it could be a multifunctional protein (Tuteja et al., 2014).
Psp68 provided salinity stress tolerance in transgenic tobacco and transgenic rice by reducing oxidative stress and improving photosynthesis machinery (Banu et al., 2014). However, very little is known about p68 protein in plant system and it has not been functionally or biochemically characterized in detail. The role of p68 and molecular target of this gene in response to stress tolerance in leguminous plants have also not been reported so far.

\section{Materials and Methods}

\section{Psp68gene, plasmid and Agrobacterium tumefaciens strain}

Agrobacterium tumefaciens strain LBA4404 containing pCAMBIA1300 harboring Psp68 gene was used for genetic transformation experiment. This strain with the above mentioned gene was procured from Dr. Narender K. Tuteja, ICGEB, Delhi

Preparation of Agrobacterium inoculum harboring pCAMBIA1300-Psp68 plasmid and Agrobacterium- mediated transformation of pigeon pea with Psp68 gene

A single colony from fresh bacterial culture raised from glycerol stock culture carrying The Agrobacterium strain LBA4404 was inoculated in $20 \mathrm{ml} \mathrm{LB}$ medium broth supplemented with kanamycin $(50 \mathrm{mg} / \mathrm{ml})$, streptomycin $(50 \mathrm{mg} / \mathrm{ml})$ and rifampicin $(50$ $\mathrm{mg} / \mathrm{ml}$ ) and incubated at $28^{\circ} \mathrm{C}$ on orbital shaker overnight (100 rpm).

Transgenic pigeon pea plants containing Psp68 gene were developed using the protocol for which patent has been filed (Patent Application No.201811012099).Transformation efficiency was calculated based on the PCR analysis of putative $\mathrm{T}_{0}$ plants. 


\section{Molecular analysis of the transformants}

Total genomic DNA was isolated from young leaves of wild type and transformed plants following the CTAB method (Saghai-Maroof et al., 1984).PCR analysis was performed to amplify fragments of Psp68 gene using gene specific primers. Reactions were carried out in $20 \mu \mathrm{l}$ reaction mixture containing $50 \mathrm{ng}$ DNA, $2 \mu \mathrm{l}$ of $10 \quad \mathrm{X}$ PCR buffer (GBiosciences) with $\mathrm{MgCl}_{2}, 0.5 \mu \mathrm{l}$ of $10 \mathrm{mM}$ of each forward and reverse primer, $0.5 \mu l$ of 10 $\mathrm{mM}$ dNTP and 2.5U Taq DNA polymerase. The DNA extracted from wild type plants was used as a negative control, the pCAMBIA 1300-Psp68 as a positive control while the reaction mix without DNA as water blank. The PCR reaction profile comprised of 35 cycles, with strand separation at $95^{\circ} \mathrm{C}$ for 4 min, annealing at $52.5{ }^{\circ} \mathrm{C}$ for $30 \mathrm{~s}$ and extension at $72{ }^{\circ} \mathrm{C}$ for $1 \mathrm{~min}$. The program was extended for $10 \mathrm{~min}$ at $72{ }^{\circ} \mathrm{C}$. The products were electrophoresed on a $1.5 \%$ agarose gel, stained with ethidium bromide and visualized under ultraviolet light (Sambrook et al., 1989).

\section{Physio-biochemical analysis of transgenic} plants under salt stress

Transgenic and non-transgenic pigeon pea plants were raised under pot culture conditions in dune sand and were subjected to $75 \mathrm{mM} \mathrm{NaCl}$ stress 15 days after sowing. Various physio-biochemical parameters like relative water content, chlorophyll content, electrolyte leakage, lipid peroxidation, proline content, total soluble sugar content, catalase and peroxidase activity were recorded 4 days and 8 days after treatment.

\section{Statistical Analysis}

All the experiments were performed in triplicates and statistical analysis was carried out on physiological data recorded on $\mathrm{T}_{1}$ generation using two factorial CRD
(Completely Randomized Design) test in OPSTAT programme (Sheoran et al., 1998).

\section{Results and Discussion}

Development of transgenic pigeon pea plants carrying Psp68 gene transformation of pigeon pea var. Manak using Psp68 gene

The transgenic pigeon pea plants carrying Psp68 gene were developed using an efficient Agrobacterium-mediated transformation protocol for which a patent has been filed (Kharb et al., 2018 Patent Application No.201811012099) (Fig. 1).

\section{Molecular characterization of transgenic pigeon pea plants carrying $P$ sp68 gene}

The putative transgenic plants were screened for the presence of Psp68 gene in $\mathrm{T}_{0}$ generation through PCR using gene-specific primers. An amplified fragment of $1.8 \mathrm{~kb}$ confirmed the presence of Psp68 gene in the plasmid DNA. Out of 100 plants screened for the presence of $P$ sp 68 gene, 16 plants showed a clear and sharp band of $1.8 \mathrm{~kb}$, representing a transformation efficiency of 16\% (Fig. 2A).

\section{PCR analysis of $T_{1}$ transgenic pigeon pea} plants carrying Psp68 gene

Seeds collected from $T_{0}$ generation plants were sown in transgenic greenhouse to raise $\mathrm{T}_{1}$ generation. $\mathrm{T}_{1}$ generation plants (ten plants from $\mathrm{T}_{0}$ each line) were screened through direct PCR kit (Phire plant direct PCR kit) using gene-specific primers. PCR analysis showed the amplification of $540 \mathrm{bp}$ fragment in the transgenic plants (Fig. 2B).

Evaluation of transgene efficacy in salt stress tolerance through physiobiochemical analysis

Healthy PCR positive $T_{1}$ generation plants were selected for physio-biochemical analysis 
to study transgene efficacy under salt stress. Various stress indices like chlorophyll content, relative water content, electrolyte leakage, lipid peroxidation, proline content, total soluble sugar content, catalase and peroxidase activity were estimated for the selected transgenic plants after $4^{\text {th }}$ and $8^{\text {th }}$ day of $75 \mathrm{mM}$ salt treatment.

\section{Effect of Salinity stress on Chlorophyll content and Relative water content}

To access the effect of salinity on Chlorophyll (Chl), Chl a, Chl b, total Chl and Chl a: b was measured in transgenic lines and WT plants. Salinity stress $(75 \mathrm{mM} \mathrm{NaCl})$ significantly reduced the Chla, Chlb and total $\mathrm{Chl}$ in transgenic lines and WT plants but the extent of reduction was higher in WT than transgenic lines. The minimum chlorophyll content was observed in wild type plants 4 DAT $(0.22 \mathrm{mg} / \mathrm{g} \mathrm{FW})$ and 8 DAT $(0.20 \mathrm{mg} / \mathrm{g}$ FW) under $75 \mathrm{mM} \mathrm{NaCl}$ salt stress whereas chlorophyll content was $0.29 \mathrm{mg} / \mathrm{g} \mathrm{FW}$ (4 DAT) and $0.24 \mathrm{mg} / \mathrm{g}$ FW (8 DAT) in wild type control (non stressed) plants. Transgenic line 53, showed highest chlorophyll content on 4 DAT $(0.56 \mathrm{mg} / \mathrm{g} \mathrm{FW})$ and 8 DAT $(0.55$ $\mathrm{mg} / \mathrm{g} \mathrm{FW}$ ) under $75 \mathrm{mM} \mathrm{NaCl}$ salt stress (Fig. 3A) Relative water content too has a significant influence on photosynthesis (Surender et al., 2013), a reduction by 5\% in RWC leads to reduction in photosynthesis by 40 to $50 \%$ Slatyer (1955).

Relative water content of the transgenic and wild-type plants decreased under stress conditions. The minimum relative water content was observed in wild type plants 4 DAT (42.86\%) and 8 DAT (23.09\%) under 75 $\mathrm{mM} \mathrm{NaCl}$ salt stress whereas relative water content was $71.46 \%$ (4 DAT) and $69.51 \%$ (8 DAT) in wild type control plants. RWC increased 0.72 fold 4 DAT and 1.99 fold 8 DAT in transgenic line 53 over wild-type under stress (Fig. 3B).
Less oxidative stress in $\boldsymbol{T}_{1}$ transgenic pigeon pea plants

Abiotic stresses including salinity cause overproduction of ROS, which leads to oxidative stress in plants. Therefore, the indicators of oxidative stress such as lipid peroxidation, electrolyte leakage were studied in Psp68 expressing transgenic lines and WT plants (Figure 4 A-B). High concentration of salt $(75 \mathrm{mM} \mathrm{NaCl})$ significantly increased the extent of oxidative damage and it was significantly higher in WT as compared to Psp68 carrying transgenic pigeon pea lines. Electrolyte leakage and lipid peroxidation increased in the transgenic and wild-type plants under stress conditions. The maximum electrolyte leakage was observed in wild type plants 4 DAT $(72.55 \%)$ and 8 DAT $(80.96 \%)$ under $75 \mathrm{mM} \mathrm{NaCl}$ salt stress whereas electrolyte leakage was $32.57 \%$ (4 DAT) and $39.06 \%$ (8 DAT) in wild type control plants. The minimum electrolyte leakage was observed in transgenic line 53, 4 DAT (18.77\%) and 8 DAT (27.67\%) under $75 \mathrm{mM}$ $\mathrm{NaCl}$ salt stress. Under stress transgenic plants were able to maintain lower electrolyte leakage as compared to wild-type plants. The highest lipid peroxidation was observed in wild type plants 4 DAT $(3.28 \mu \mathrm{mol} / \mathrm{g} \mathrm{FW})$ and 8 DAT $(3.88 \mu \mathrm{mol} / \mathrm{g} \mathrm{FW})$ under $75 \mathrm{mM} \mathrm{NaCl}$ salt stress whereas lipid peroxidation was $1.38 \mu \mathrm{mol} / \mathrm{g} \mathrm{FW}$ (4 DAT) and $1.49 \mu \mathrm{mol} / \mathrm{g} \mathrm{FW}$ (8 DAT) in wild type control (non stress) plants. Transgenic plants were able to maintain lower MDA content as compared to wild-type plants under stress conditions. Lipid peroxidation in transgenic line 53 was decreased by $69.40 \% 4$ DAT and $63.61 \%$ 8DAT over wild-type under stress conditions.

Effect of salt stress on osmolytes in wild type and $T_{1}$ Transgenic pigeon pea plants

All plants produce higher levels of osmolytes in the cytosol and other organelles to 
overcome the negative impact of osmotic stress (Ahmad et al., 2016; Latef and Miransari, 2014). Total soluble sugars maintain cell homeostasis under abiotic stresses by acting as osmolytes (Rosa et al., 2009) and accumulation of proline under stress conditions might serve as a sink for excess reductants, providing the $\mathrm{NAD}^{+}$and $\mathrm{NADP}^{+}$necessary for maintenance of respiratory and photosynthetic processes (Kishor et al.,, 2005) and has been considered as an acclamatory mechanism of salt stress (Hayat et al., 2012). Both transgenic and wild-type plants showed increase in total soluble sugar and proline content under stress conditions. The minimum total soluble sugar content was observed in wild type plants 4 DAT $(56.53 \mathrm{mg} / \mathrm{g} \mathrm{FW})$ and 8 DAT $(61.20$ $\mathrm{mg} / \mathrm{g} \mathrm{FW}$ ) under $75 \mathrm{mM} \mathrm{NaCl}$ salt stress whereas the total soluble sugar content was $51.93 \mathrm{mg} / \mathrm{g} \mathrm{FW}$ (4 DAT) and $53.73 \mathrm{mg} / \mathrm{g} \mathrm{FW}$ (8 DAT) in wild type control (non stressed) plants.. Total soluble sugar increased by $22.7 \% 4$ DAT and $21.4 \%$ 8DAT in transgenic line 53 over wild-type under stress. The minimum proline content was observed in wild type plants 4 DAT $(1.73 \mu \mathrm{mol} / \mathrm{g} \mathrm{FW})$ and 8 DAT $(1.88 \mu \mathrm{mol} / \mathrm{g} \quad \mathrm{FW})$ under 75 $\mathrm{mMNaCl}$ salt stress whereas the proline content was $0.433 \mu \mathrm{mol} / \mathrm{g} \mathrm{FW}$ (4 DAT) and $0.61 \mu \mathrm{mol} / \mathrm{g}$ FW (8 DAT) in wild type control plants. Proline content increased by 2.4 fold 4 DAT and 2.2 fold 8 DAT in transgenic line 53 over wild-type under stress. Under stress conditions, the transgenic line 53 maintained maximum total soluble sugar and proline content (Fig. 5A-B).

\section{Psp68 Enhances ROS Scavenging Capacity in $T_{1}$ Transgenic pigeon pea plants}

Salinity stress is known to cause ROS induced oxidative damage in plant cells. Therefore, we analyzed the response of enzymatic antioxidants like catalase and peroxidase in $\mathrm{T}_{1}$ transgenic lines and WT plants under salinity stress. Antioxidant defense machinery protects the plant cells from ROS induced oxidative damage. Catalase and peroxidase activity of both transgenic and wild-type plants increased under stress conditions. The minimum catalase activity was observed in wild type plants 4 DAT (6.34 units/g FW) and 8 DAT (8.11 units/g FW) under $75 \mathrm{mM} \mathrm{NaCl}$ salt stress whereas the catalase activity was 3.80 units/g FW (4 DAT) and 4.55 units/g FW (8 DAT) in wild type control plants. The highest catalase activity was observed in transgenic line 53, 4 DAT (22.58 units/g FW) and 8 DAT (26.15 units/g FW) under $75 \mathrm{mM}$ $\mathrm{NaCl}$ salt stress. Catalase activity in the transgenic line 53 increased by 2.5 fold 4 DAT and 2.2 fold 8 DAT over wild-type under stress. The minimum peroxidase activity was observed in wild type plants 4 DAT (0.159 units/g FW) and 8 DAT (0.165 units/g FW) under $75 \mathrm{mM} \mathrm{NaCl}$ salt stress whereas the peroxidase activity was 0.046 units/g FW (4 DAT) and 0.050 units/g FW (8 DAT) in wild type control (non stress) plants. The highest peroxidase activity was observed in transgenic line 53, 4 DAT (0.50 units/g FW) and 8 DAT (0.55 units/g FW) under $75 \mathrm{mM} \mathrm{NaCl}$ salt stress. Peroxidase activity increased by 2.14 fold 4 DAT and 2.33 fold 8 DAT in transgenic line 53 over wild-type under stress (Fig.6A-B).

\section{Effect of $75 \mathrm{mM} \mathrm{NaCl}$ salt stress on wild- type and transgenic pigeon pea plants}

Wild-type plants died as they were not able to tolerate salt concentration of $75 \mathrm{mM} \mathrm{NaCl}$ whereas transgenic plants survived under stressed conditions (Fig.7).

Genetically modified (GM) crop plants are the fastest recognized technology in agriculture (James, 2010) but biosafety issue is a crucial factor for the development of transgenics and global applications of different genetically modified products. 
Horizontal transfer of antibiotic-resistance genes to animal and human gut bacteria seem as major biosafety concerns in GM crops (Dale et al., 2002).Therefore, it is required to develop new techniques for the production of 'clean' marker-free transgenic plants. In the present study, marker-free transgenic pigeon pea plants have been developed against salinity stress by introducing Psp68 gene through a rapid, simple and efficient transformation system which bypasses the tissue culture procedures. Transformation following the characterization using PCR represented transformation frequency of $16.0 \%$.

Salinization is recognized as the main threat to environmental resources and human health in many countries, affecting almost 1 billion ha worldwide/globally (Metternicht and Zinck, 2003). The production and productivity of pigeon pea is adversely affected by salinity suggesting it as a salt sensitive leguminous crop (Tayyab et al., 2016). Advances in molecular and genomic tools have been widely applied to understand the mechanism underlying stress tolerance. Further, the release of pigeon pea genome sequence has paved a way to modify pigeon pea with desired genes to improve salinity tolerance (Varshney et al., 2012). Engineering crop plants with improved salinity tolerance rely on expression of genes that are involved in signaling and regulatory pathways (Wang et al., 2018) or genes that code for proteins involved in stress tolerance (Assaha et al., 2017) or enzymes that regulate pathways involved in synthesis of functional and structural metabolites (Anjaneyulu et al., 2014). It is evident many genes including DEAD-box helicases get triggered by stress, which play a crucial role in various abiotic stresses. Banu et al., (2014) reported that the transcript of Psp68 is accumulated at a high level and almost equally in every part (roots, leaves, tendrils and flowers) of the pea plant.
Therefore, this gene could be a potential candidate for developing stress-tolerant transgenic plants. The Psp68 protein contains all conserved domains that are characteristic of the DEAD-box proteins including ' $Q$ ' and 'GG' motif(Tanner et al.,) In plant the first report of stress induced helicase gene came by cDNA microarray analysis of 1300 Arabidopsis genes where the authors reported a DEAD-box helicase gene (accession number AB050574) as a cold stress-inducible gene suggesting a new role of helicases in stress signalling (Seki et al.,). Later, many plant DEAD-box helicases were identified and found to be activated in response to changing environmental conditions (Owttrim, 2006; Vashisht and Tuteja, 2006; Gill et al., 2013; Mahajan and Tuteja,2005) In barley, a salt-responsive transcript HVD1 is induced under salt stress, cold stress, and ABA treatment (Nakamura et al., 2004). AvDH1 is another DEAD-box helicase gene from the halophyte dogbane plant that also strongly upregulated in response to salinity and low temperature (Liu et al., 2008). Under normal growth conditions relatively high level of basal expression of the pea p68 gene in different plant parts implies its function in growth and/or development processes. Under salt treatment, a single species of pea $p 68$ mRNA was detected abundantly and constitutively in the tissues examined. This indicated that basic activity of cells might be regulated by pea $p 68$ under salt stress.

Genome-wide expression analysis of many DEAD-box helicase genes have been identified and suggested that these genes might be stress regulated (Kant et al., 2005). Overexpression analysis in different DEADbox helicases has been shown to provide multiple abiotic stress tolerance in crop plants by regulating different signalling pathways (Vashisht et al., 2005; Mishra et al., 2005; Tuteja et al., 2013). For example, overexpression of PDH45 and OsSUV3 gene 
provided salinity stress tolerance in tobacco and rice respectively (Mishra et al., 2005; Tuteja et al., 2013). LOS4 and RCF1 mutant analysis in Arabidopsis was found to play an important role in response to cold and heat stress (Gong et al., 2005; Guan et al., 2013). In our study, we showed that marker free Psp68 provides salinity stress tolerance in pgeon pea.

The reduction in leaf chlorophyll content under abiotic stress has been attributed to the destruction of chlorophyll pigments in various crop plants (Tuteja et al., 2012; Zhang et al., 2012; Huda et al., 2013). We observed that stress-induced chlorophyll loss was enhanced in WT plant while transgenic lines retained more chlorophyll. This finding has strong correlation with the previous studies in other DEAD-box helicases (Mishra et al., 2005; Dang et al., 2011; Sahoo et al., 2013). Hence it indicates the expression of Psp68 gene could have positive effects on the growth and photosynthetic metabolism process. Under salt stress conditions, plants usually adjust their osmotic potential to maintain turgor pressure (Boyer et al., 2008) thus maintaing cellular hydration levels.In present investigation, decrease in RWC was observed in both WT and transgenic plants with salt treatment but decline in RWC was more in wild-type plants under $75 \mathrm{mM} \mathrm{NaCl}$ stress as compared to transgenic plants.

Stress also leads to the rapid production of ROS including $\mathrm{H}_{2} \mathrm{O}_{2}$ in plant tissues that ultimately cause damages to the cell membrane and other cellular components such as plasma membrane, mitochondria and chloroplasts (Gill et al., 2013; Huda et al., 2013). Hence, to avoid any stress-induced injuries plant needs to develop efficient mechanism to remove excess ROS from cells. Enzymatic ROS-scavenging and nonenzymatic antioxidants system are such mechanisms in the plant cells that prevent ROS induced oxidative damage (Gill et al., 2010; Gill et al., 2012; Bhattarcharjee, 2012). Catalase and peroxidase are the major enzymes that are known to be involved in scavenging of cellular production of $\mathrm{H}_{2} \mathrm{O}_{2}$ (Willekens et al., 1994; Noctor and Foyer, 1998).

Fig.1 Vector map of the binary vector pCAMBIA 1300 carrying Psp68 gene

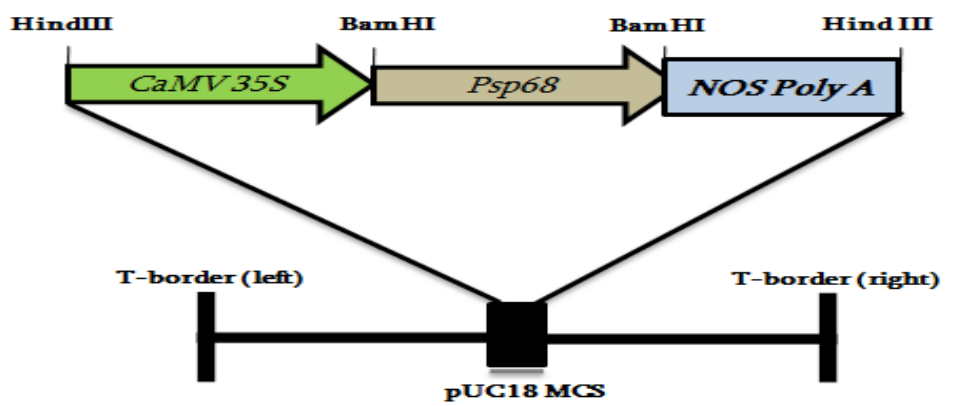

Fig.2 PCR analysis of transformants (A) $1.5 \%$ agarose gel showing amplification of $1.8 \mathrm{~kb}$ 
fragment of Psp68 gene. (B) $1.5 \%$ agarose gel showing amplification of $540 \mathrm{bp}$ fragment of Psp68 gene in T1 generation plants. Lanes L-1 kb ladder, PC: Positive Control (Plasmid DNA), NC: Negative Control (Genomic DNA of wild-type)
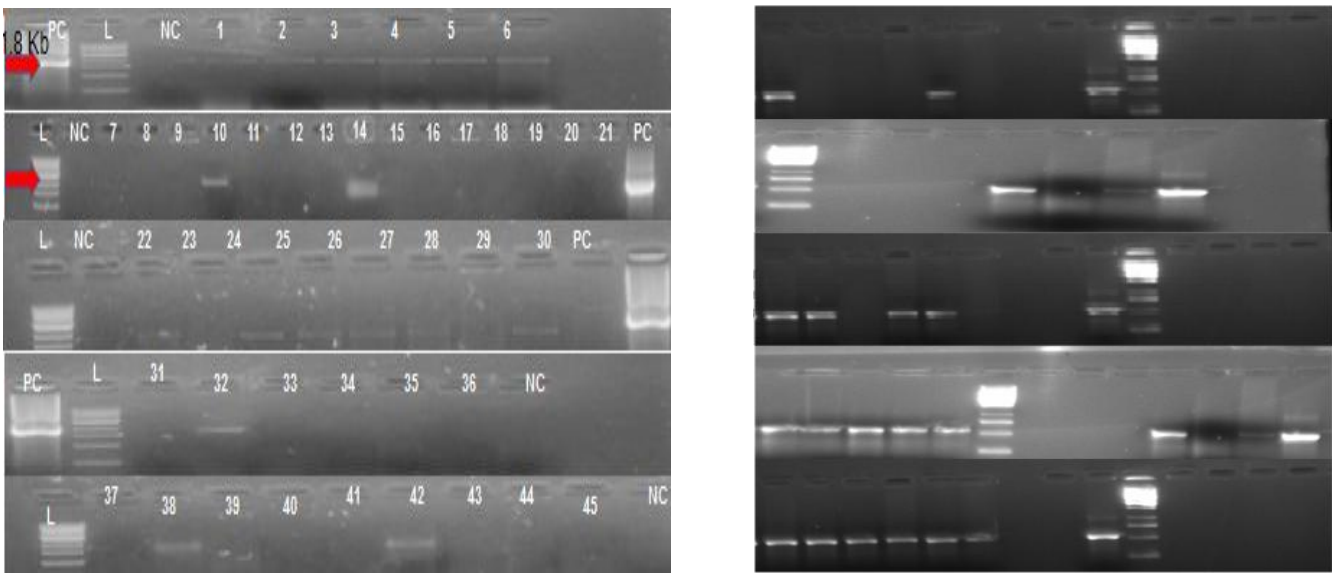

Fig.3 (A) Effect of $75 \mathrm{mM}$ salt stress on chlorophyll content and (B) Relative water content in wild-type and $\mathrm{T} 1$ transgenic pigeon pea plants
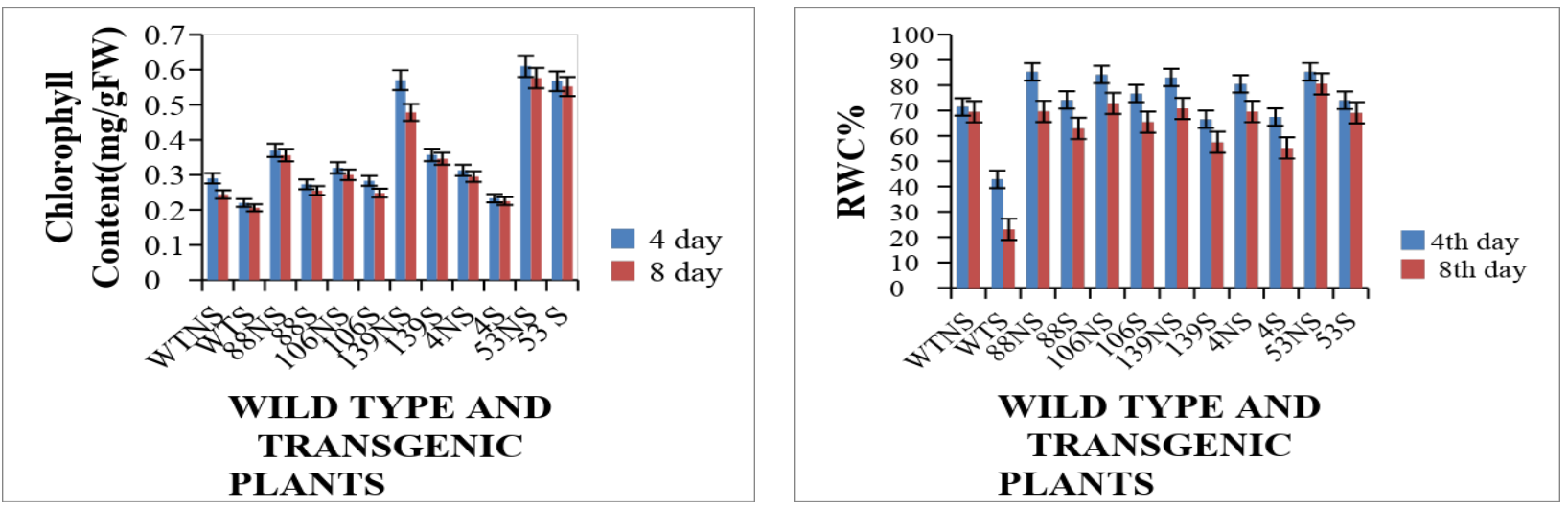

Fig.4 Effect of $75 \mathrm{mM}$ salt stress on (A) electrolyte leakage and (B) MDA content in wild-type and $\mathrm{T} 1$ transgenic pigeon pea plants
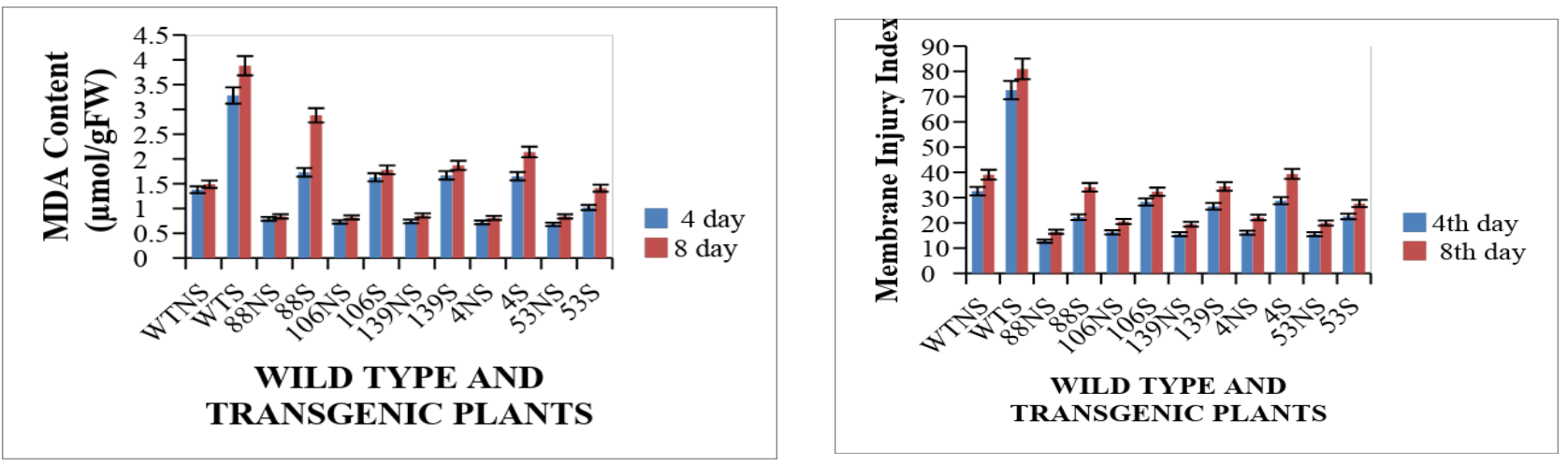

Fig.5 Effect of $75 \mathrm{mM}$ salt stress on (A) Total soluble sugar content (B) Proline content in wild- 
type and $\mathrm{T} 1$ transgenic pigeon pea plants
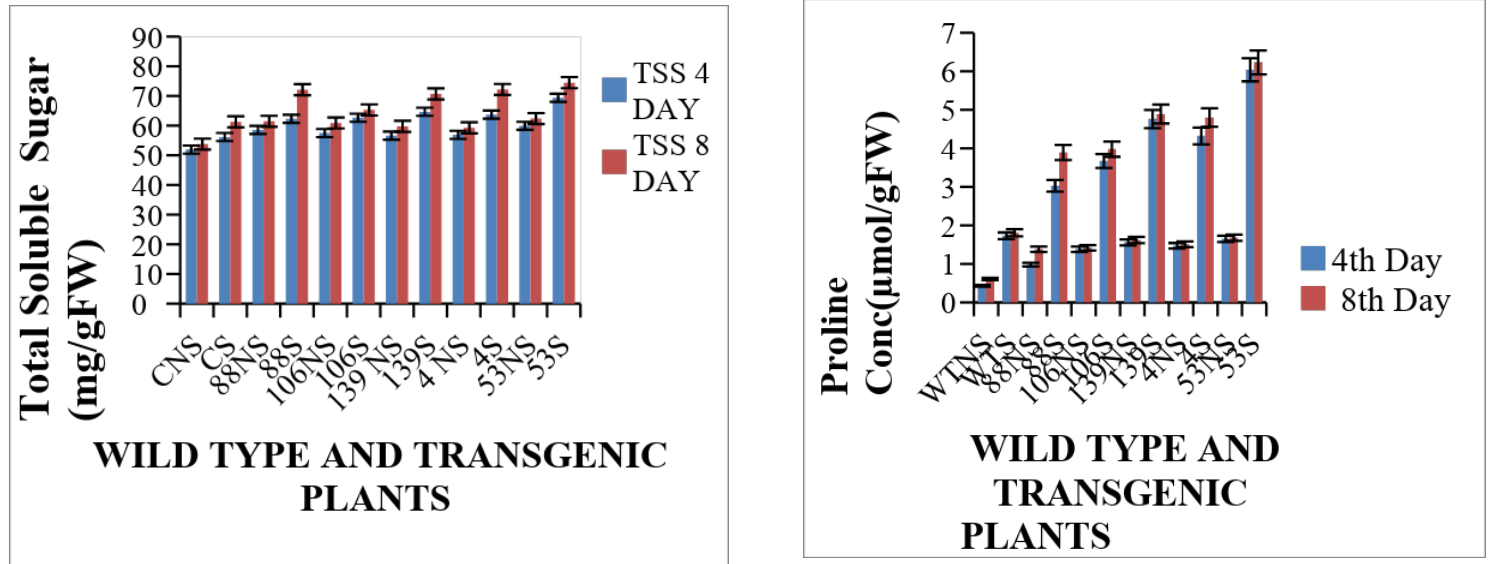

Fig.6 Expression of Psp68 showed less oxidative damage by modulating the ROS machinery under salinity stress. (A) Catalase activity (B) Peroxidase activity in wild-type and T1 transgenic pigeon pea plants under $75 \mathrm{mM}$ Salt stress
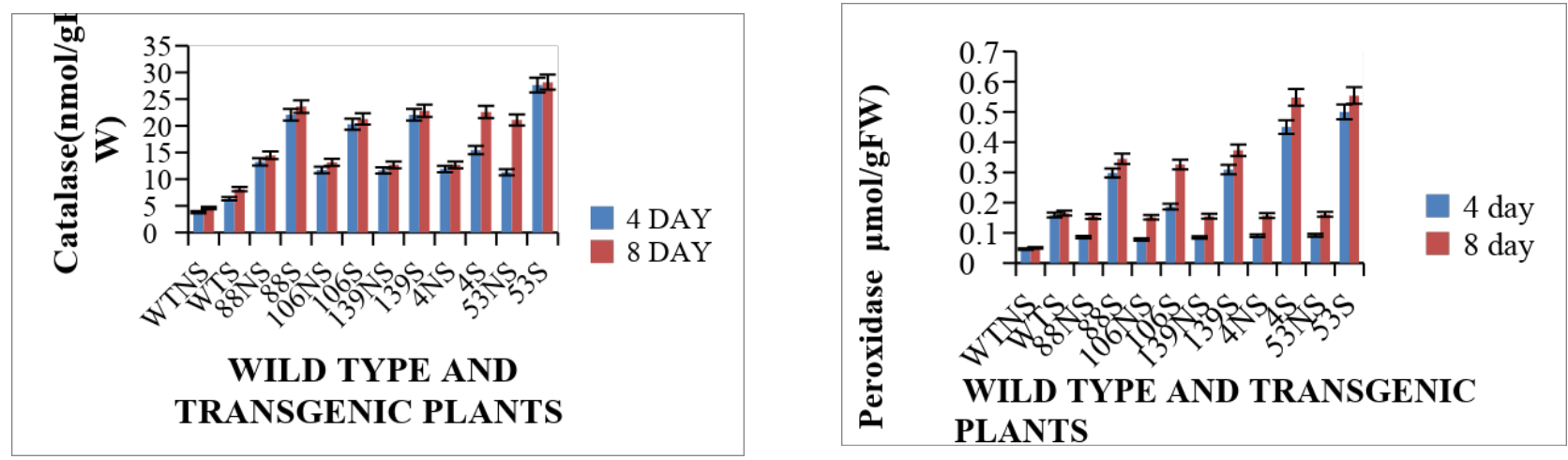

Fig.7 Effect of $75 \mathrm{mM} \mathrm{NaCl}$ salt stress on wild-type and transgenic pigeon pea plants

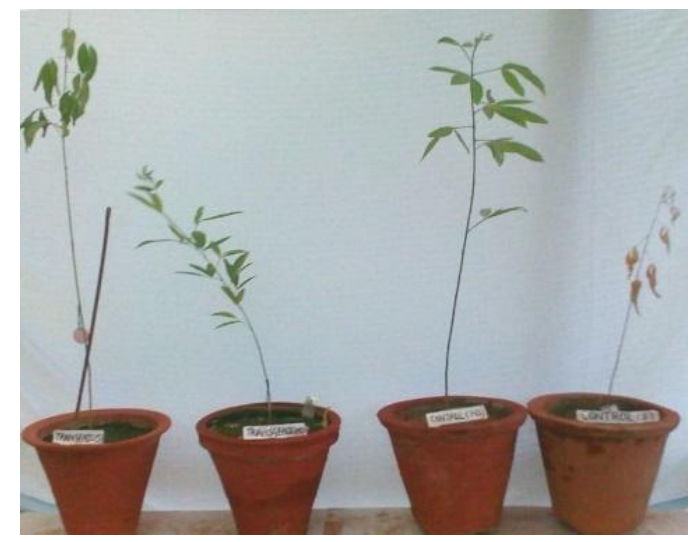


Interestingly in this study the activity of these enzymes increased in transgenic lines in response to stress treatment indicating that transgenic lines could readily scavenge $\mathrm{H}_{2} \mathrm{O}_{2}$ either decomposing it through increased activity of catalase or peroxidase. Previously, a number of overexpression studies have shown an increased activity of catalase and peroxidase in response to abiotic stress treatment (Jiang et al., 2002; Luna et al., 2004; Mhamdi et al., 2010; Gill et al., 2013). Moreover, plants produce higher levels of osmolytes in the cytosol and other organelles to overcome the negative impact of osmotic stress (Ahmad et al., 2016; Latef and Miransari, 2014). Increase in total soluble sugars helps to bring down the osmotic potential of cell sap below that of growing medium, enabling the uptake of water by cells under salt stress (Benzarti et al., 2014) and accumulation of proline under stress has been considered as an acclamatory mechanism of salt stress (Hayat et al., 2012). In present investigation, salt stress resulted in accumulation of proline and total soluble sugars in both wild-type and transgenic pigeon pea plants.

In conclusion, the involvement of DEAD-box helicases in various metabolic processes in plant cells might have general implications. The present study provides new insights into the novel function of marker free Psp68 gene in conferring salinity stress tolerance in transgenic pigeon pea plant. Salt stress affected the various physio-biochemical parameters resulting in decrease in chlorophyll and relative water content and an increase in electrolyte leakage, peroxidation, total soluble sugar content and proline content. The activity of antioxidant enzymes, catalase and peroxidase increased with salt stress. Among all the transgenic lines, line 53 was found promising for salt tolerance in terms of various physio-biochemical parameters studied under salt stress conditions. This study showed the role of Psp68 coding for DEAD Box RNA helicase in mitigating salt stress as transgenic plants performed well under salt stress conditions.

\section{References}

Ahmad, P., Abdel Latef, A. A., Hashem, A., Abd Allah, E. F., Gucel, S. and Tran, L.S. P. (2018). Nitric oxide mitigates salt stress by regulating levels of osmolytes and antioxidant enzymes in chickpea. Frontiers in Plant Science, 7, 347, 1-11. doi:10.3389/fpls.2016.00347.

Ashraf, M. (2010). Inducing drought tolerance in plants: Recent advances. Biotechnology Advances, 28(1), 169-183. doi:10.1016/j.biotechadv.2009.11.005.

Assaha, D. V. M., Ueda, A., Saneoka, H., AlYahyai, R. and Yaish, M. W. (2017). The role of $\mathrm{Na}+$ and $\mathrm{K}+$ transporters in salt stress adaptation in glycophytes. Frontiers in Physiology, 8(509), 1-19. doi:10.3389/fphys.2017.00509.

Anjaneyulu, E., Reddy, P. S., Sunita, M. S., Kishor, P. B. K.\& Meriga, B. (2014). Salt tolerance and activity of antioxidative enzymes of transgenic finger millet overexpressing a vacuolar $\mathrm{H}+-$ pyrophosphatase gene (SbVPPase) from Sorghum bicolor. Journal of Plant Physiology, 171(10), 789-798. doi:10.1016/j.jplph.2014.02.001.

Assaha, D. V. M., Ueda, A., Saneoka, H., AlYahyai, R. and Yaish, M. W. (2017). The role of $\mathrm{Na}+$ and $\mathrm{K}+$ transporters in salt stress adaptation in glycophytes. Frontiers in Physiology, 8(509), 1-19. doi:10.3389/fphys.2017.00509.

Banu, S.A., Kazi, Md., Huda, K., Sahoo, K.R., Garg, B., Tula, S., Shahinul, S.M., Tuteja, R., Tuteja, N. Pea p68 Imparts Salinity Stress Tolerance in Rice by Scavenging of ROS-Mediated $\mathrm{H} 2 \mathrm{O} 2$ and Interacts with Argonaute Plant Molecular Biology, doi: 10.1007/s11105-014-0748-7.

Bates, G.J., Nicol, S.M., Wilson, B.J., Jacobs, A.M., Bourdon, J.C., Wardrop, J., et 
al.,(2005) The DEAD box protein p68: a novel transcriptional coactivator of the p53 tumour suppressor. The EMBO journal, 24, 543-553. doi: 10.1038/sj.emboj.7600550.

Benzarti, M., Rejeb, K. Ben, Messedi, D., Mna, A. Ben, Hessini, K., Ksontini, M., Abdelly, C. and Debez, A. (2014). Effect of high salinity on Atriplex portulacoides: Growth, leaf water relations and solute accumulation in relation with osmotic adjustment. South African Journal of Botany, 95, 70-77. doi: 10.1016/j.sajb.2014.08.009.

Boyer, J. S., James, R. A., Munns, R., Condon, T. A. G. and Passioura, J. B. (2008). Osmotic adjustment leads to anomalously low estimates of relative water content in wheat and barley. Functional Plant Biology, $\quad 35(11), \quad$ 1172-1182. doi:10.1071/FP08157.

Bhattacharjee S (2012) The language of reactive oxygen species signaling in plants. $J$ Bot.

Chen, J., Wan, S., Liu, H., Fan, S., Zhang, Y., Wang, W., Xia, M., Yuan, R., Deng, F. and Shen, F. (2016). Overexpression of an Apocynum venetum DEAD-Box Helicase Gene (AvDH1) in Cotton Confers Salinity Tolerance and Increases Yield in a Saline Field. Front Plant Science, $\quad 6, \quad 1227 . \quad$ doi: 10.3389/fpls.2015.01227.

Dale, P.J., Clarke, B. and Fontes, E.M. (2002) Potential for the environmental impact of transgenic crops. Nature biotechnology, 20, 567-574. doi:10.1038/nbt0602-567.

Dang HQ, Tran NQ, Gill SS, Tuteja R, Tuteja N (2011) A single subunit MCM6 from pea promotes salinity stress tolerance without affecting yield. Plant Mol Biol, 76, 1934.

Flowers, T. J. (2004). Improving crop salt tolerance. Journal of Experimental Botany, 55(396), 307-319. doi:10.1093/jxb/erh003

Ishizuka, A., Siomi, M.C. and Siomi, H. (2002) A Drosophila fragile $\mathrm{X}$ protein interacts with components of RNAi and ribosomal proteins. Genes and development, 16, 2497-2508.doi: 10.1101/gad.1022002.

Fuller-Pace, F.V. (2006) DExD/H box RNA helicases: multifunctional proteins with important roles in transcriptional regulation. Nucleic acids research, 34, 4206-4215.

Gill SS, Tuteja N (2010) Reactive oxygen species and antioxidant machinery in abiotic stress tolerance in crop plants. Plant Physiol Biochem, 48, 909-939.

Gill SS, Singh LP, Gill R, Tuteja N (2012) Generation and scavenging of reactive oxygen species in plants under stress. In: Tuteja N, Gill SS, Tiburcio AF, Tuteja R (eds) Improving crop resistance to abiotic stress. Wiley-VCH Verlag GmbH and Co. KGaA, Germany, 49-70.

Gustafson, E.A. and Wessel, G.M. (2010) DEAD-box helicases: posttranslational regulation and function. Biochemical and biophysical research communications, 395: $1-6 . \quad$ doi: $10.1016 / \mathrm{j} . \mathrm{bbrc}$. 2010.02.172.

Gong, Z., Dong, C.H., Lee, H., Zhu, J., Xiong, L., Gong, D., et al., (2005) A DEAD box RNA helicase is essential for mRNA export and important for development and stress responses in Arabidopsis. The Plant cell, $\quad 17, \quad 256-267$. doi:10.1105/tpc.104.027557.

Guan, Q., Wu, J., Zhang, Y., Jiang, C., Liu, R., Chai, C., et al., (2013) A DEAD box RNA helicase is critical for pre-mRNA splicing, cold-responsive gene regulation, and cold tolerance in Arabidopsis. The Plant cell, 25, 342-356. doi: 10.1105/tpc.112.108340.

Gill SS, Tajrishi M, Madan M, Tuteja N (2013) A DESD-box helicase functions in salinity stress tolerance by improving photosynthesis and antioxidant machinery in rice (Oryza sativa L. cv. PB1). Plant Mol Biol, 82, 1-22

Huang, Y. and Liu, Z.R. (2002) The ATPase, RNA unwinding, and RNA binding activities of recombinant p68 RNA helicase. The Journal of biological chemistry, 277, 12810-12815. 
Hayat, S., Hayat, Q., Alyemeni, M. N., Wani, A. S., Pichtel, J. and Ahmad, A. (2012). Role of proline under changing environments: a review. Plant Signaling and Behavior, 7(11), 1456-66. doi:10.4161/psb.21949.

Heath, R. L.\& Packer, L. (1968). Photoperoxidation in isolated chloroplasts. Archives of Biochemistry and Biophysics, 125(1), 189-198. doi:10.1016/0003-9861(68)90654-1.

Huda KM, Banu MS, Garg B, Tula S, Tuteja R, et al., (2013) OsACA6, a P-type IIB $\mathrm{Ca}^{2+}$ ATPase promotes salinity and drought stress tolerance in tobacco by ROS scavenging and enhancing the expression of stress-responsive genes. Plant J, 76, 997-1015.

Jangra, S., Mishra, A., Kamboj, D., Yadav, N. R. and Yadav, R. C. (2017). Engineering abiotic stress tolerance traits for mitigating climate change. In Plant Biotechnology: Recent Advancements and Developments, 59-73. doi:10.1007/978981-10-4732-9_3.

James, C. (2010) A global overview of biotech (GM) crops: adoption, impact and future prospects. GM crops, 1, 8-12. doi: 10.4161/gmcr.1.1.9756.

Jiang M, Zhang J (2002) Water stress-induced abscisic acid accumulation triggers the increased generation of reactive oxygen species and upregulates the activities of antioxidant enzymes in maize leaves. $J$ Exp Bot, 53, 2401-2410.

Kant, P., Kant, S., Gordon, M., Shaked, R. and Barak, S. (2007). STRESS RESPONSE SUPPRESSOR1 and STRESS RESPONSE SUPPRESSOR2, two DEAD-box RNA helicases that attenuate Arabidopsis responses to multiple abiotic stresses. Plant Physiology, 145(3), 814 30. doi:10.1104/pp.107.099895.

Kar, A., Fushimi, K., Zhou, X., Ray, P., Shi, C., Chen, X., et al., (2011) RNA helicase p68 (DDX5) regulates tau exon 10 splicing by modulating a stem-loop structure at the $5^{\prime}$ splice site. Molecular and cellular biology, 31, 1812-1821. doi: 10.1128/MCB.01149-10.

Kim, M. J., Kim, H. J., Pak, J. H., Cho, H. S., Choi, H. K., Jung, H. W., Lee, D. H. and Chung, Y. S. (2017). Overexpression of AtSZF2 from Arabidopsis showed enhanced tolerance to salt stress in soybean. Plant Breeding and Biotechnology, 5(1), 1-15. doi:10.9787/PBB.2017.5.1.1.

Kharb, P., Batra, P. and Singh,R. (2018) An efficient method of genetic transformation in pigeon pea using Agrobacterium. Patent Application No. 201811012099.

Kumar, S., Kalita, A., Srivastava, R. and Sahoo, L. (2017). Co-expression of Arabidopsis NHX1 and bar improves the tolerance to salinity, oxidative stress, and herbicide in transgenic mungbean. Frontiers in Plant Science, $\quad$ 8(1896), $1-18$. doi:10.3389/fpls.2017.01896.

Kavi Kishor P.B., Sangam, S., Amrutha, R.N., Sri Laxmi, P., Naidu, K. R., Rao, K.R.S.S., Sreenath Rao, Reddy, K.J., Theriappan, P. and Sreenivasulu, N. (2005). Regulation of proline biosynthesis, degradation, uptake and transport in higher plants: Its implications in plant growth and abiotic stress tolerance. Current Science, 88 (3), 424438.

Lamaoui, M., Jemo, M., Datla, R. and Bekkaoui, F. (2018). Heat and drought stresses in crops and approaches for their mitigation. Frontiers in Chemistry, 6(26), 1-14. doi:10.3389/fchem.2018.00026.

Linder, P. and Fuller-Pace, F (2013) Looking back on the birth of DEAD-box RNA helicases. BBA - Gene Regulatory Mechanisms, doi: 10.1016/j.bbagrm. 2013.03.007.

Linder, P. and Jankowsky, E. (2011) From unwinding to clamping - the DEAD boxRNA helicase family. Nature reviews. Molecular cell biology, 12: 505-516. doi: $10.1038 / \mathrm{nrm} 3154$.

Li, D., Liu, H., Zhang, H., Wang, X. and Song, F. (2008) OsBIRH1, a DEAD-box RNA helicase with functions in modulating 
defence responses against pathogen infection and oxidative stress. Journal of experimental botany, 59: 2133-2146.

Liu, H.Y., Nefsky, B.S. and Walworth, N.C. (2002) The Ded1 DEAD box helicase interacts with Chk1 and $\mathrm{Cdc} 2$. The Journal of biological chemistry, 277: 2637-2643.

Latef, A. A. H. and Miransari M. (2014) The Role of Arbuscular Mycorrhizal Fungi in Alleviation of Salt Stress. In: Miransari M. (eds) Use of Microbes for the Alleviation of Soil Stresses. Springer, New York, NY, pp-23-38.

Luna CM, Pastori GM, Driscoll S, Groten K, Bernard S, et al., (2004) Drought controls on $\mathrm{H}_{2} \mathrm{O}_{2}$ accumulation, catalase (CAT) activity and CAT gene expression in wheat. $J$ Exp Bot,56,417-423.

Metternicht G.I., Zinck J.A. Remote sensing of soil salinity: potentials and constraints. Remote Sens. Environ.,85,1-20. doi: 10.1016/S0034-4257(02)00188-8.

Munns, R. (2005). Genes and salt tolerance: bringing them together. New Phytologist, 167(3), 645-663. doi:10.1111/j.14698137.2005.01487.x.

Machado R.M.A., Serralheiro R.P. (2017) Soil salinity: effect on vegetable crop growth. Management practices to prevent and mitigate soil salinization. Horticulturae, 3,30 .

doi.org/10.3390/horticulturae3020030.

Mhamdi A, Queval G, Chaouch S, Vanderauwera S, Van Breusegem F, et al., (2010) Catalase function in plants: a focus on Arabidopsis mutants as stressmimic models. J Exp Bot, 61, 4107-4320.

Mahajan S, Tuteja N (2005) Cold, salinity and drought stresses: an overview. Arch Biochem Biophys, 444, 139-158.

Nakamura T, Muramoto Y, Takabe T (2004) Structural and transcriptional characterization of a salt-responsive gene encoding putative ATP-dependent RNA helicase in barley. Plant Sci,167,63-70.

Noctor G, Foyer CH (1998) Ascorbate glutathione: Keeping active oxygen under control. Annu Rev Plant Physiol Plant Mol Biol, 49, 249-279.

Owttrim GW (2006) RNA helicases and abiotic stress. Nucleic Acids Res 34: 3220-3230. Pradhan, A., Chauhan, V.S. and Tuteja, R. (2005b) Plasmodium falciparum DNA helicase 60 is a schizont stage specific, bipolar and dual helicase stimulated by PKC phosphorylation. Molecular and biochemical parasitology, 144, 133-141. doi: 10.1016/j.molbiopara.2005.08.006.

Rasool, S., Ahmad, A., Siddiqi, T. O. and Ahmad, P. (2013). Changes in growth, lipid peroxidation and some key antioxidant enzymes in chickpea genotypes under salt stress. Acta Physiologiae Plantarum,, 35(4), 10391050. doi:10.1007/s11738-012-1142-4.

Rahneshan, Z., Nasibi, F. and Moghadam, A. A. (2018). Effects of salinity stress on some growth, physiological, biochemical parameters and nutrients in two pistachio (Pistacia vera L.) rootstocks. Journal of Plant Interactions, 13(1), 73-82. doi:10.1080/17429145. 2018.1424355.

Rosa, M., Prado, C., Podazza, G., Interdonato, R., González, J.A., Hilal, M., and Prado, E.F. (2009). Soluble sugarsMetabolism, sensing and abiotic stress. Plant Signal Behav. 4(5), 388-393.doi: 10.4161/psb.4.5.8294.

Shivakumara, T. N., Sreevathsa, R., Dash, P. K., Sheshshayee, M. S., Papolu, P. K., Rao, U., Tuteja, N. and UdayaKumar, M. (2017). Overexpression of Pea DNA Helicase 45 (PDH45) imparts tolerance to multiple abiotic stresses in chili (Capsicum annuum L.). Scientific Reports, 7(1), 1-12. doi:10.1038/s41598017-02589-0.

Stevenson, R.J., Hamilton, S.J., MacCallum, D.E., Hall, P.A. and Fuller-Pace, F.V. (1998) Expression of the 'dead box' RNA helicase p68 is developmentally and growth regulated and correlates with organ differentiation/maturation in the foetus. The Journal of pathology, 184,351-359. 
Saghai-Maroof, M. A., Soliman, K. M., Jorgensen, R. A. and Allard, R. W. (1984). Ribosomal DNA spacer-length polymorphisms in barley: Mendelian inheritance, chromosomal location, and population dynamics. Proceedings of the National Academy of Sciences, 81(24), 8014-8.

Sambrook, J., Fritsch, E. F. and Maniatis, T. (1989). Molecular cloning: a laboratory manual.

Cold Spring Harbor Laboratory Sheoran, O. P.,Tonk, D. S., Kaushik, L. S., Hasija, R.C. \&Pannu, R.S. (1998). Statistical Software Package for Agricultural Research Workers. Recent Advances in information theory, Statistics $x i$ and Computer Applications by D.S. Hooda\& R.C. Hasija Department of Mathematics Statistics, CCS HAU, Hisar pp-139-143.

Surendar, K.K., Devi, D.D., Ravi, I., Jeyakuma, P., Velayudham, K. (2013). Effect of Water Stress on Leaf Temperature, Transpiration Rate, Stomatal Diffusive Resistance and Yield of Banana. Plant Gene and Trait, 4(8), doi: 10.5376/pgt.2013.04.0008

Slatyer R.O., 1955, Australian Journal of Agriculture Research, 61, 365-377 http://dx.doi.org/10.1071/AR9550365.

Seki M, Narusaka M, Abe H, Kasuga M, Yamaguchi-Shinozaki K, et al., (2001) Monitoring the expression pattern of 1300 Arabidopsis genes under drought and cold stresses by using a full-length cDNA microarray. Plant Cell, 13, 61-72.

Sahoo RK, Gill SS, Tuteja N (2012) Pea DNA helicase 45 promotes salinity stress tolerance in IR64 rice with improved yield. Plant Signal Behav, 7, 1037-1041.

Sanan-Mishra N, Pham XH, Sopory SK, Tuteja $N$ (2005) Pea DNA helicase 45 overexpression in tobacco confers high salinity tolerance without affecting yield. Proc. Natl Acad. Sci. USA, 102, 509-514.

Tuteja, N. (1997) Unraveling DNA helicases from plant cells. Plant molecular biology, $33,947-952$.
Tuteja, N. (2000) Plant cell and viral helicases: essential enzymes for nucleic acid transactions. Critical Reviews in Plant Sciences, 19,449-478.

Tuteja, N. and Tuteja, R. (2004a) Prokaryotic and eukaryotic DNA helicases. Essential molecular motor proteins for cellular machinery. European journal of biochemistry / FEBS, 271, 1835-1848.

Tuteja, N. and Tuteja, R. (2004b) Unraveling DNA helicases. Motif, structure, mechanism and function. European journal of biochemistry / FEBS, 271, 1849-1863.

Tuteja, N., Banu, M. S. A., Huda, K. M. K., Gill, S. S., Jain, P., Pham, X. H. and Tuteja, R. (2014). Pea p68, a DEAD-box helicase, provides salinity stress tolerance in transgenic tobacco by reducing oxidative stress and improving photosynthesis machinery. PloS One, 9(5), e98287. doi: 10.1371/journal. pone.0098287.

Tayyab, A., Azeem, M., Ahmad, N., Ahmad, R., Qasim, M. (2016). Salt Stress Responses of Pigeon Pea (Cajanus cajan) on Growth, Yield and Some Biochemical Attributes.

Pakistan Journal of Botany, 48(4), p. 1353-1360.

Tuteja N, Gill SS, Tuteja R (2012) Helicases in Improving Abiotic Stress Tolerance in Crop Plants. In: Tuteja N, Gill SS, Tiburcio AF, Tuteja R (eds) Improving crop resistance to abiotic stress. WileyVCH Verlag GmbH and Co, KGaA, Germany, 433-445.

Tuteja N, Sahoo RK, Garg B, Tuteja R (2013) OsSUV3 dual helicase functions in salinity stress tolerance by maintaining photosynthesis and antioxidant machinery in rice (Oryza sativa L. cv. IR64). Plant J, 76, 115-127.

Tanner NK, Cordin O, Banroques J, Doe're M, Linder P (2003) The Q motif: a newly identified motif in DEAD box helicases may regulate ATP binding and hydrolysis. Mol Cell, 11, 127-138. 
Varshney, R. K., Song, C., Saxena, R. K., Azam, S., Yu, S., Sharpe, A. G., Cannon, S., Baek, J., Rosen, B. D. Taran, B., Millan, T., Zhang, X., Ramsay, L. D., Iwata, A., Wang, Y., Nelson, W., Farmer, A. D., Gaur P. M., Soderlund, C., Penmetsa, R. V., Xu, C., Bharti, A. K., He, W., Winter, P., Zhao, S., Hane, J. K., Carrasquilla-Garcia, N., Condie, J. A., Upadhaya, H. D., Luo, M. D., Thudi, M., Gowda, C. L. L., Singh, N. P., Lichtenzveig, J., Gali, K. K., Rubio, J., Nadarajan, N., Dolezel, J., Bansal, K. C., Xu, X., Edwards, D., Zhang, G., Kahl, G., Gil, J., Singh, K. B., Datta, S. K., Jackson, S. A., Wang, J. and Cook, D. R. (2012). Draft genome sequence of pigeon pea (Cajnus cajan) an orphan legume of resource poor farmers. Nature Biotechnology, 31(3), 83-89. doi:10.1038/nbt.2491

Vashisht A, Tuteja N (2006) Stress responsive DEAD box helicases: a new pathway to engineer plant stress tolerance. $J$ Photochem Photobiol 84,150-160.

Vashisht A, Pradhan A, Tuteja R, Tuteja N (2005) Cold and salinity stress-induced pea bipolar pea DNA helicase 47 is involved in protein synthesis and stimulated by phosphorylation with protein kinase C. Plant J. 44, 76-87.

Wang, H., Gao, X., Yang, J.J. and Liu, Z.R. (2013) Interaction between p68 RNA helicase and $\mathrm{Ca} 2+$-calmodulin promotes cell migration and metastasis. Nature communications, 4, 1354.

Willekens H, Langebartels C, Tire C, Van Montagu M, Inze D, et al., (1994) Differential expression of catalase genes in Nicotiana plumbaginifolia (L.). Proc. Natl Acad. Sci. USA, 91, 10450-10454.

Yu, L. H., Wu, S. J., Peng, Y. S., Liu, R. N., Chen, X., Zhao, P., Xu, P., Zhu, J. B., Jiao G. L., Pei, Y. and Xiang, C. B. (2016). Arabidopsis EDT1/HDG11 improves drought and salt tolerance in cotton and poplar and increases cotton yield in the field. Plant Biotechnology Journal, 14(1), 72-84. doi: 10.1111/pbi.12358.

Zörb, C., Geilfus, M.C., Dietz M.C. Salinity and crop yield. Plant Biology, https://doi.org/10.1111/plb.12884.

Zhu, J. K. (2000). Genetic analysis of plant salt tolerance using Arabidopsis. Plant Physiology, 124(3), 941-8. doi:10.1104/PP.124.3.941.

\section{How to cite this article:}

Neha and Pushpa Kharb. 2019. Psp68, A Dead Box Helicase Confers Salinity Tolerance in Transgenic Pigeon Pea. Int.J.Curr.Microbiol.App.Sci. 8(04): 309-324. doi: https://doi.org/10.20546/ijcmas.2019.804.035 